\title{
Public Relations Planning In Building A Private University Branding During The Covid-19 Pandemic (A Case Study at Universitas Swadaya Gunung Jati Cirebon)
}

\author{
Iman Cahyanto ${ }^{1}$, Iim Wasliman ${ }^{2}$, Fahruroji $^{3}$ Supyan Sauri $^{4}$ \\ ${ }^{1)}$ Universitas Wiralodra, Jl Ir. H. Juanda Km. 03 Indramayu \\ ${ }^{2,3,4)}$ Universitas Islam Nusantara, Jl. Soekarno Hatta Bandung
}

*Coresponding Author

Email : iman.cahyanto@unwir.ac.id

\begin{abstract}
This research is focused on investigating the public relations planning in building a private university branding during the COVID-19 pandemic. University branding is a strategic effort in strengthening the identity of the institution. In practice, branding can be done in various ways, such as by utilizing information technology. During the COVID-19 pandemic, the frequency of using internet-based media increased dramatically. The phenomenon that occurs in public relations during a pandemic is the changing pattern of media publications, from conventional media and internet-based media to internet-based media. The phenomenon changed the public relations management structure in building university branding and the lack of maximum branding achievements that have been set in the previous program before the pandemic. The concept of public relations management in universities establishes theoretical principles in formulating and implementing public relations management to build university branding. Referring to the management theory of George R. Terry who stated that the management is carried out based on the main points of the formulation of organizational goals (Riinawati, 2019). The implementation of university branding in the current pandemic situation and conditions must not be outside the corridor of management functions. This study aimed to find out how to plan university branding during the pandemic. Based on the results of the research on public relations planning in building the branding of private universities during the pandemic, the implementation process of public relations management planning has not been formulated in a standardized manner so that it cannot improve public relations performance during a pandemic in a timely manner. This has an impact on achievement that is not optimal. In order for the university's public relations performance to increase and the implementation of university public relations management to improve the brand, and provide the expected feedback, the university's public relations planner needs to reformulate the university's public relations management structure. The right formulation of the results of this research is a planning model that involves information technology as a domain of digitization in public relations management. The current technology involvement is expected to improve the university's branding performance during the pandemic. More specifically, public relations management planning in building private university branding during the pandemic needs to develop systematic and strategic steps that refer to the rules of planning function in public relations management to be able to improve the university branding process. The preparation of the branding plan in the form of an activity program does not include: creative content adapted to current conditions, human resource development planning and public relations support facilities such as training on the use of information technology for public relations staff. Procurement of computer equipment, property for making videos and making information technology studios..
\end{abstract}

Keywords: Public Relations Planning, Public Relations Management, University Branding, University Digital Branding.

\section{INTRODUCTION}

Branding is an institution's effort to create a good image that aims to gain public sympathy and strengthen identity so that the public can distinguish one university from another. This is in line with the theory proposed by Kotler who says that branding is the naming of a product or service that uses a symbol or other sign with the aim of distinguishing 
the product from products made by others (Keller, 2009). Currently, universities in West Java are aggressively promoting their institutions through internet-based social networks. This is because the situation and condition of the COVID-19 pandemic has not yet ended. In a situation like this, the public relations department at the university requires changing the university's branding and promotion strategy that is adapted to the pandemic conditions. Observing branding at several universities in West Java through the observation of information publication traffic on official university accounts, there is an increase in the frequency and number of information publications. The branding process is part of public relations management in universities. One of the ways in which public relations in universities is implemented is by publishing activities that have been and will be carried out by the university or other work units within the university. The phenomenon that occurs in public relations during a pandemic is the changing pattern of media publications, which originally used two media, namely conventional media and internet-based media, now using internet-based media more. this has an impact on changes in the public relations management structure in building university branding and the lack of maximum branding achievements that have been set in the previous program before the pandemic hit.

The concept of public relations management in universities establishes theoretical principles in formulating and implementing public relations management to build university branding. Referring to the management theory of George R. Terry. He stated that management is carried out based on the main points of the formulation of organizational goals (Riinawati, 2019). The implementation of university branding in the current pandemic situation and conditions must not be outside the corridor of management functions. Based on a preliminary study conducted at the Universitas Swadaya Gunung Jati University, Cirebon West Java. There are differences in branding strategies so it is necessary to adjust them to the programs that have been set before the pandemic. This hinders the university's branding and promotion process. This phenomenon is the background for conducting research with the aim of obtaining information and analyzing university branding planning during the COVID-19 pandemic. This study explicitly aims to identify branding planning.

This study used two major theories as the main reference, namely the management theory of George R. Terry, and the branding theory created by Kotler \& Keller. This phenomenon is studied from the point of view of management theory, it requires reformulation of the university's branding strategy. The reformulation involves a program structure starting from planning, implementation, and evaluation. In its implementation, these changes require careful planning and are ready in all conditions by determining alternative solutions if there are obstacles in their implementation. The planning process certainly involves all personnel by dividing up the tasks of public relations management, this division of tasks must be distributed to all public relations personnel, by doing managing. This is in line with Terry's opinion which explains that management is an activity that involves managing, people who do managing are called managers. The manager's task is to manage the division of operational tasks and achievements that must be completed by the organization so that the tendency to carry out tasks by one person can be eliminated (Terry, 2014). In informative communication theory explaining how to communicate using the media, Shannon stated that the media here plays an important role. Depending on the media itself, if the media is good, communication is assumed to be carried out well, and vice versa (Shannon \& Weaver, 1998). This theory explains how to communicate efficiently by using channels in the form of radio waves. In this theory, the analogy is that if the media used to communicate is damaged, such as radio waves that have problems, the communication plane is damaged, then the message conveyed is not conveyed properly. Likewise with the university branding program, if the theory is implemented in the 
current situation and condition of the university's branding implementation, then the covid-19 pandemic will be an obstacle to branding communication.

From the point of view of public relations management in universities, it is explained that management is principally the arrangement in the work system of the organization by implementing the management function as a whole. Referring to the interests of the organization, the role of management can change according to the goals or objectives of the organization, so the understanding of management can change depending on the situation and organizational goals. As explained by R. Supomo that the term management contains three meanings, namely (1) management as a process; (2) become a group of people who implement management; (3) the disciplines of science and the art of managing (Supomo, 2018). While university public relations focuses on both internal and external services and network maintenance based on the tri dharma of higher education.

This opinion has the same purpose, including requiring planning and implementing and evaluating. In higher education institutions, public relations an play a role in managing internal relations including: relations with educators (lecturers), educational staff (administrative staff), students, and alumni, as well as external relations such as relations with the general public, press, government agencies, private institutions. The COVID-19 pandemic has affected policy changes in every sector, it is inevitable that the education sector will also be affected. One of the government policies in the education sector is the implementation of distance education. The implementation of distance education in several universities in West Java has become commonplace, however, the instrument for implementing higher education is not only that, but there are other sectors such as research and community service which are in face-to-face format.

\section{RESEARCH METHODS}

This study used a qualitative approach, describe the phenomena that occur, and the need for deepening research. The qualitative approach was chosen because it is considered appropriate to answer problems in public relations management to build university branding. Public relations management research problems require study and observation and deepening to find meaning in public relations management and branding at universities. As stated by John W. Creswell that qualitative research seeks to create an understanding of the phenomena that occur from the participant's point of view, create a new pattern, and different behaviors at one time (Creswell, 2017).

This research method is based on the philosophy of post-positivism, namely the researcher becomes an instrument in research. In line with Mahmud (2011) who wrote that descriptive research is research that seeks to describe or observe problems systematically and accurately regarding the facts and properties of certain objects. He further explained that descriptive research is aimed at describing and describing and mapping facts based on a certain perspective or frame of mind (Mahmud, 2011). Sugiyono explained that in research that uses a qualitative approach, the data collection process is carried out in natural conditions, in this process participant observation is carried out as a primary data source, data collection techniques are carried out by interviewing and collecting documentation. (Sugiyono, 2016). For the purposes of this study, data collection techniques using triangulation techniques. Data collection techniques in this study using documents, recordings, archives, interviews, and direct observation. 


\section{RESULTS AND DISCUSSION}

University branding can be interpreted as a management system that has the aim of building the image of the university. In this management, public relations are the right tool to use in building the university's image. To achieve the desired image or brand, the branding strategy is arranged by management which is then called public relations management. Public relations management is a construction that is built to make it easier to achieve branding targets, after the brand is formed and achieves branding goals, it is hoped that it can improve university services to the academic community, education staff, and other services. In its implementation, public relations management to build university branding requires the right organizational structure, this is intended so that the division of responsibilities, duties and authorities can be distributed properly. Based on the observations and interviews as well as the documentation that has been done, Universitas Swadaya Gunung Jati (UGJ) has a strategy management with the division of authority and task of branding the university according to the needs. The structure of public relations at the UGJ leading sector is under the vice rector IV who specializes in public relations and cooperation. This structure is important in the implementation of public relations management, this is in accordance with the theory put forward by George R. Terry that to achieve a goal requires a joint effort from individuals who carry out predetermined organizational tasks. This process is known as the management function. The main management functions according to Terry consist of: Planning, Organizing, Actuating, and Controlling which we know as the acronym POAC (Terry, 2014).

Referring to the theory, this study sets a reference in researching public relations management to build university branding by conducting an analysis using management functions as a standard. The management functions are formulated into: Planning, implementation, evaluation, obstacles, solutions and the results that have been achieved.

The focus of this research related to the theory put forward by George R. Terry about the ideas or assumptions about the future by describing the formulation of activities to be carried out with the target of achieving goals. (Terry, 2014). George R. Terry stated that in the preparation of planning, at least 12 points must be considered in the planning concept as follows:

a. Planning is compiling a program structure with various considerations from the results of the evaluation or it can also be arranged as the implementation of ideas and ideas as the beginning of program preparation. Next, the planning concept can also be interpreted as a process for determining alternatives, this alternative is prepared as a reserve which is often termed a second plan with the aim of replacing the same program if the implementation is predicted to be problematic, or cannot be implemented at all. This alternative planning does not replace the substance of the program, it only changes the method of implementation or the format and packaging of program implementation. Plans that are made suddenly may not / are not good results because then we do not / lack of time to be able to think well;

b. Planning must be realistic and economical, sufficient time is expected so that we can think better, so that the planning we make is expected to be better too;

c. The need for coordination in planning. Because planning activities in an organization involve various fields and tend to be complex, in its implementation it is necessary to adjust between sectors, and cannot be done suddenly;

d. Planning must be based on experience, knowledge, and intuition, to make plans it needs to be based on experience, knowledge, and intuition. With his experience managers easily plan well. With these experiences, managers can analyze the weaknesses and 
advantages of past planning actions that can be applied to material for making future plans;

e. Planning must be based on participation, if a manager feels that he has sufficient experience and knowledge in making plans, then it may be enough to handle the planning alone or only with the help of some of his staff;

f. Planning must take into account all possibilities;

g. Planning must be flexible (flexible);

h. Planning must be able to become the basis for other management functions, namely organizing, directing, coordinating, and controlling;

i. Planning must be able to maximize the available facilities, in making plans the company must be able to translate this;

j. Planning must be dynamic, in making plans we must passively be flexible in the sense that planning is possible to change when situations and conditions change;

k. Planning must be enough time, planning means thinking ahead, before the action itself is carried out. Thus, the manager will have enough time so that he can contemplate, think about, observe, discuss, determine alternatives and prepare everything.

1. Planning should be based on research, to develop a plan, it is actually not enough if it is only based on knowledge, experience, and intuition. However, a manager needs complete, reliable and actual data.

The research findings at the Universitas Swadaya Gunung Jati, in principle, are in accordance with the considerations written in the theory. This is evidenced by the existence of alternative plans for each activity held. The alternative plan is not written in the planning concept but is listed in the chart mapping the potential obstacles to the implementation of these activities.

The process of preparing a public relations plan to build university branding is divided into three parts, namely: short-term plans, medium-term plans, and long-term plans. The division of the plan is a program implementation strategy that has been determined at a time. University branding is a program that has a continuous nature so it requires careful planning.

The 12 points that must be considered in the preparation of the above planning are normative rules, in practice the preparation of planning must also be adaptive to the variables that influence it such as information technology, social environment, and organizational atmosphere.

The development of technology is currently increasingly rapid, especially now that there is a pandemic that is endemic throughout the world so that, forcing life activities to depend on information technology. It is inevitable that all human needs can be met by involving information technology as a medium. Likewise in the practice of public relations management, in carrying out university public relations propaganda, public relations have involved the media for a long time, however, currently media involvement is shifting from conventional media to internet-based online media. For this reason, planning must be adaptive to information technology. Next, planning must be adaptive to the social environment, the context of the social environment is an important part to consider in the preparation of the university branding plan because the changing conditions of the social structure affect the branding returns carried out. For example, during the current pandemic, the tendency for changes in human lifestyles is very high, such as the daily life practices that are usually done conventionally are forced to turn digital, for example searching for information on news, food, fashion and others before the pandemic is carried out directly: to meet the needs of news information, people look for it in newspapers (newspapers), magazines, and tabloids. To find food, people go directly to restaurants, cafes, etc. To meet the needs of clothing (Fashion) people can go directly to boutiques, malls or distributions, but during a pandemic, all activities are limited with the aim 
of suppressing the spread of COVID-19 so that all daily needs are searched digitally through applications on smartphones. Various application services to meet the needs of human life have existed since before the pandemic, it's just that the frequency of users of these applications is limited. The application service is widely used by socialites and young people known as the millennial generation. However, when the epidemic hit, internet user traffic increased, almost all groups used it to fulfill various needs.

Apart from that, the decline in purchasing power cannot be countered by anything. In social conditions like this, public relations planning must adapt to conditions when social changes occur. The term digital branding is not a new term in public relations; however, the percentage of digitalization is currently increasing and is no longer even a second term but has become the main and must be done. Conditions of social change like this must be the basis for planning.

Planning must be adaptive to the organizational atmosphere; this variable is important to consider in planning because a healthy organizational atmosphere and situation determines the quality of ideas and ideas in planning. Referring to the notion of management put forward by George R. Terry states that management is a series of work processes based on organizational goals that are carried out collectively consisting of several people through the direction and guidance of the group. (Terry, 2014). In the context of planning "organizational goals" in the management definition above, it can be interpreted as situations and conditions that occur in the organization. Organizational goals are the top management so that the process to achieve them requires proper and accurate planning. Planning accuracy can be influenced by the above variables, one of which is the organizational atmosphere.

This is closely related to the readiness of organizational personnel with their respective main tasks and functions. Personnel in organizations are often referred to as manpower. From a planning point of view, manpower is an estimate of the involvement of organizational personnel with the optimal number required in a program or activity. The involvement of this personnel becomes an important and vital part, to carry out the main tasks and support the implementation of activities. The determination of the number of personnel can be determined according to the scale of the planned activity or program, it can be a small number or a large number.

It can be concluded that the preparation of public relations management planning to build university branding normatively must pay attention to the things that influence it so that planning can be used as a reference as an alternative implementation when facing obstacles. A complete plan is a plan that can predict the constraints that may occur, so that preventive efforts can be made to minimize the possibility of failure in its implementation. Planning is a process to achieve goals, the statement can be interpreted that planning is a road that is full of signs to the goal so that in planning it must be clear, set targets, processes, evaluations and other variables such as solutions that are prepared in case of failure.

Frida Kusumastuti in Zainal Mukarom stated that at the planning stage of a public relations program, the first thing to do is to set goals. The stated objectives are:

1) Maintenance of mutual understanding;

2) Growing and maintaining trust;

3) Creating cooperation and maintaining harmony.

Thus, the essence of the purpose of public relations is to grow and maintain good relations so that trust and mutual trust grow. (Mukarom \& Laksana, 2015). In a simple perspective, public relations have a goal to create, maintain, and improve the good image of the institution.

These public relations goals must be included in the planning. Universitas Swadaya Gunung Jati seeks to create a good image for the university by doing things that do not go out 
of the corridor of educational standards and innovating in implementing university branding. Public relations in the world of education are very concerned about ethics in conveying information to the public, even though the information is in the form of advertisements, for example. The rules of advertising are still considered with the style of education. This is very different from commercial advertising, not a few commercial ads contain negative propaganda by inserting satire to their competitors. In educational advertisements made by university public relations, these things are avoided by making university advertisements based on the material advantages possessed, faculties and study programs available at each university by conveying a profile of graduate achievement, a description of career opportunities and competencies that will be achieved. The material is described and packaged into information that is easily understood by the public. The propaganda that is made does not contain a black campaign, but rather an invitation and education.

The next goal of public relations is to improve the good image of the institution, this is the accumulation of the previous goals so that the good image is feedback from the branding process. A good image does not necessarily manifest in public opinion, however, through a long and continuous process and consistency in branding. The good image of the institution is the goal of branding, so that in planning the branding, it must be really mature and clearly set the time-term target. The main return from improving the good image of the university is the improvement of the university's services to the internal and external public.

This is in line with the previous research entitled Branding of Private Universities (Case Study of Marketing Public Relations Strategy of the Indonesian Christian University of Maluku) published by Rido Latuheru on the page http://ejurnal.ukim.ac.id/ Universitas Kristen Indonesia Maluku volume1 number 1-year 2019, with the result: in doing branding at the Indonesian Christian University in Maluku, the first thing to do was a brand campaign. To carry out a campaign, what needs to be underlined is the selection of campaign materials and must be in line with the identity, vision and mission of the institution. Next is Brand Recognition Positioning, which is an effort to familiarize the brand in people's memories by refining every activity. The three Brand Preferences, UKIM through the Research Institute and PkM also bring innovation. (Latuheru, 2018). Next is a study entitled The Role of Public Relations in the Establishment of Branding Institutions for Private Islamic Religious Universities, published in the journal Tadris volume 13 No.1 in 2019. The article was written by Nur Laili Dina Hafni, Akhmad Zaini with the results: Branding in private universities needs to be carried out in order to strengthen reputation by improving performance. In addition, public relations and marketing must be integrated. (Hafni \& Zaeni, 2019).

It can be concluded that this research confirms that institutional branding is important in any condition and situation. The branding process is an inherent part of public relations management, for that the university's public relations department must have careful and strategic planning in branding the university.

The following is a public relations planning model in building university branding: 


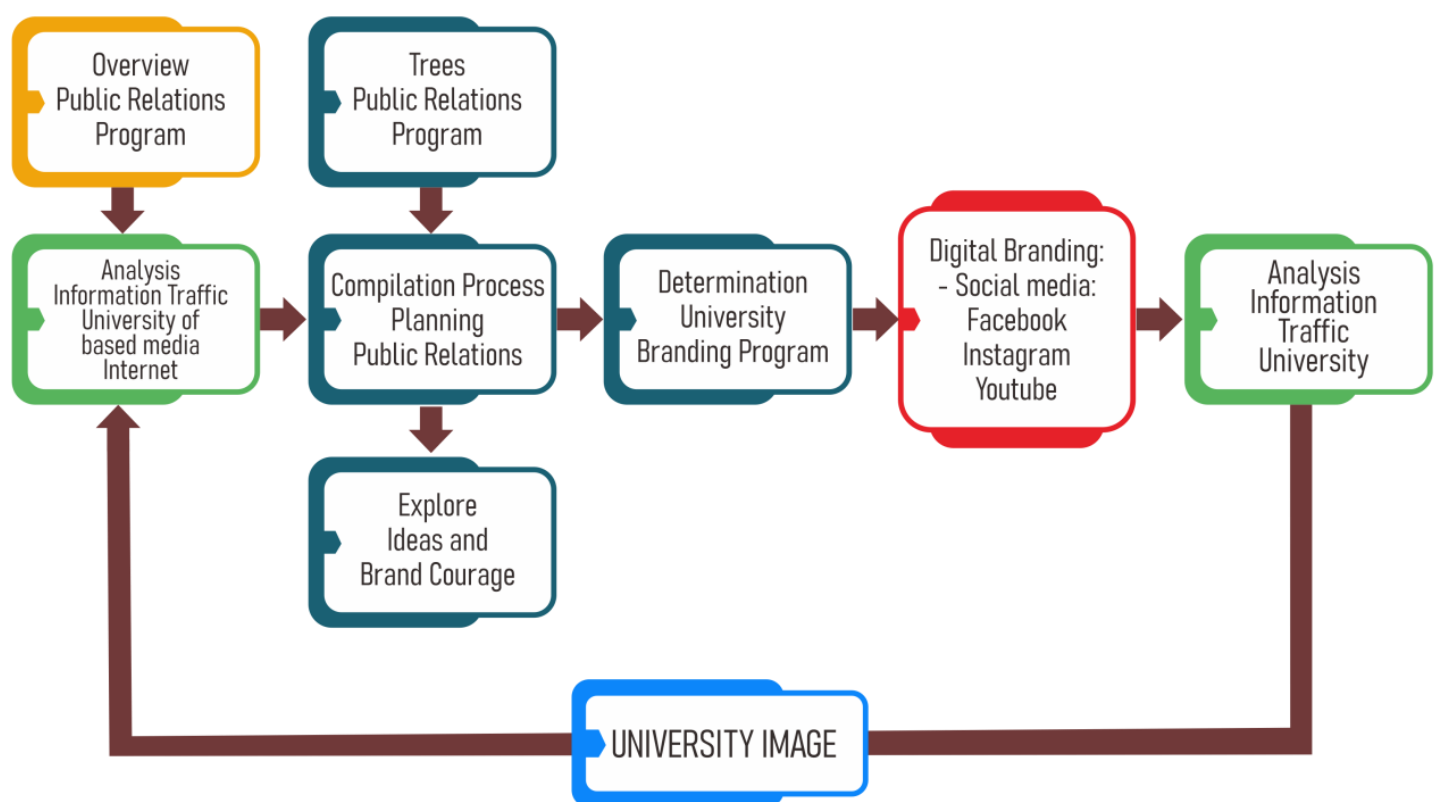

Figure 1: PR planning model in building university branding

This model is a public relations management planning implementation system involving information technology as a medium. From a micro point of view, the implementation of public relations management planning starts from analyzing the public relations program, then analyzing information traffic on social media from other universities, after getting the conclusions from the analysis then the public relations department prepares a plan by paying attention to the main data of the public relations program and exploring ideas and ideas that arise in program evaluation and analysis. The next process is to establish a branding program with branding packaging outputs that will be published on social media accounts such as: Facebook, Instagram, YouTube, etc. As a note, the follow-up plans resulting from the evaluation of the preparation of the plan become a benchmark in determining the next branding strategy. The planning process becomes a public relations management planning system and cycle in building university branding.

This concept focuses on the weight of the interrelationships and dependencies of the subsystem of the public relations management function described in the input, process, output, outcome scheme.

\section{CONCLUSION}

Based on the research results of public relations planning in building the branding of private universities during the pandemic, in principle it is in accordance with the normative rules of management. However, in practice the implementation process of public relations management planning has not been formulated in a standardized manner so that it cannot improve public relations performance during a pandemic in an appropriate manner. This has an impact on achievement that is not optimal. In order for the university's public relations performance to increase and the implementation of university public relations management to improve the brand, and provide the expected feedback, the university's public relations planner needs to reformulate the university's public relations management structure. The right formulation of the results of this research is a planning model that involves information technology as a domain of digitization in public relations management. The current technology 
involvement is expected to improve the university's branding performance during the pandemic. More specifically, public relations management planning in building private university branding during the pandemic needs to develop systematic and strategic steps that refer to the rules of planning function in public relations management to be able to improve the university branding process. The preparation of the branding plan in the form of an activity program does not include: creative content adapted to current conditions, human resource development planning and public relations support facilities such as training on the use of information technology for public relations staff. Procurement of computer equipment, property for making videos and making information technology studios. The achievements obtained from the implementation of a complete public relations management plan in building a good university branding will have implications for institutional strengthening, increasing public trust in the university and increasing the number of new student admissions

\section{REFERENCES}

Creswell, J. W. (2017). Research Design Pendekatan Metode Kualitatif Kuantitatif Dan Campuran Ed.4. Jakarta: Pustaka Pelajar.

Hafni, N. L., \& Zaeni, A. (2019). Peran Public Relation dalam Pembentukan Branding Institution Perguruan Tinggi Keagamaan Islam Swasta (Studi Kasus STIT Makhdum Ibrahim Tuban. Jurnal Tadris, 67-77.

Keller, K. d. (2009). manajemen pemasaran. Jakarta: Erlangga.

Latuheru, R. (2018). Branding Perguruan Tinggi Swasta (Studi Kasus Strategi Marketing Public Relation Universitas Kristen Indoneasia Maluku). Jurnal Badati, 105-116.

Mahmud. (2011). Metode Penelitian Pendidikan. Bandung: Pustaka Setia.

Mukarom, Z., \& Laksana, M. W. (2015). Manajemen public relation : Panduan efektif pengelolaan hubungan masyarakat. Bandung: Pustaka Setia.

Riinawati. (2019). Pengantar Teori Manajemen Komunikasi dan Organisasi. Yogyakarta: PT. Pustaka Baru.

Shannon, C. E., \& Weaver, W. (1998). The Mathematical Theory of Communication 16th Printing Edition. United State of America: The Board of Trustess of the University of Illinois.

Sugiyono. (2016). Metode Penelitian Kuantitatif, dan R\&D. Bandung: Alfabeta.

Supomo, R. (2018). Pengantar manajemen. Bandung: Yrama Widya.

Terry, G. R. (2014). Prinsip-prinsip Manajemen . Jakarta: Bum Aaksara. 